\title{
Modern problems of the product market of Russia
}

\author{
Tat'ayna Gorokhova ${ }^{1}$, Lyudmila Pushkareva ${ }^{2,3}$, and Mikhail Pushkarev ${ }^{3,4, *}$ \\ ${ }^{1}$ The National Open Institute in St. Petersburg, 197183, 6 Sestroretskaya str., St. Petersburg, Russia \\ ${ }^{2}$ North-West Institute of Management, branch of RANEPA, 199178, Sredny prospect VO, 57/43, St. \\ Petersburg, Russia \\ ${ }^{3}$ Saint Petersburg State University of Architecture and Civil Engineering, 190005, 4 Vtoraya \\ Krasnoarmeiskaya, Saint Petersburg, Russia \\ ${ }^{4}$ Saint-Petersburg State Institute of Technology, 190013, 26 Moskovsky prospect, St. Petersburg, \\ Russia
}

\begin{abstract}
Modern transformations in the economic life of society impose requirements on the reassessment of existing economic trends from the standpoint of the country's economic security. In many regions of the country, the situation on the food market is far from ideal. A significant part of the food industry is controlled by transnational corporations, and modern own agricultural production does not cover the needs of the population for significant food products. This article reveals the development trends of the domestic food market. Particular attention is paid to the development of grain farming and the formation of the bread market.
\end{abstract}

\section{Introduction}

The urgency of the problem is due to the search for ways to revive the country's own food market at the expense of Russia's domestic agricultural reserves. The economic security of the country depends on the stability of the food market, which is based on the development of the domestic agricultural sector. A country where $2 / 3$ of the food market is formed by its own production of agricultural raw materials can ensure the independence of its agricultural business and meet the demand of the population for vital food products. A particularly important branch of domestic agricultural production is grain farming. Grain farming in Russia is focused not only on the development of the food industry, providing the needs of the population for bakery products, but also on the development of the feed base of domestic cattle-breeding meat - the dairy industry and poultry farming.

It should be noted that the situation on the Russian food market is far from ideal. The objective of this study is to reveal the negative and positive trends that have developed in the food market in different regions of the country. Regional examples illustrate the features and prospects of the development of segments of the food market during the reform of agricultural production. Particular attention is paid to the development of the

\footnotetext{
*Corresponding author: malexpush@bk.ru
} 
bread market, the modern organizational structure of which determines the development of the bread cluster.

\section{Methods}

This work was done on the personal initiative of the authors using the methods of monographic description, comparative analysis, materials of scientific and practical conferences, scientific seminars and round tables, where the aforementioned issues were discussed, literary sources and official publications on the problem in the public domain.

\section{Results and Discussion}

The modern press notes that the apparent abundance of food on store shelves misleads the population in many regions of the country. The bulk of the population began to eat worse, which adversely affects the health of the younger generation. According to doctors, due to the consumption of low-quality imported frozen meat imported into the country, which has lost its beneficial properties, children develop a "protein hunger". Only in a 10-year period of reforming the economy of the agricultural sector - childhood anemia has increased more than 4 times. At the same time, the predominance of imported meat raw materials in the food market pushed domestic producers out of the market and undermined agriculture. Namely, this circumstance led to the destruction of the land use structure: fodder land, including arable land of grain crops, became unclaimed. The long-term alienation of agriculture from using it as a feed base for cattle breeding and poultry farming in the NonChernozem region led to the degradation of previously reclaimed lands, which made it possible to provide cattle-breeding farms of the country and the needs of the baking industry of the food industry earlier.

According to All-Russia Research and Development Institute of Agricultural Economics analysts, this niche has been occupied by importers. "Today in Russia, a significant part of the food industry is concentrated in the hands of multinational corporations that can control retail food prices and purchase prices for agricultural raw materials. Under the control of transnational corporations, it is estimated that about $90 \%$ of the market for wheat, coffee, corn, tobacco, jute and up to $70 \%$ of the market for bananas and natural rubber are located [4]. In the current economic situation, it is timely to approve the professor of the Russian Academy of National Economy and Public Administration (RANEPA), doctor of economic sciences L.V. Pushkareva: "Food security is part of national security, as it ensures the sustainable production of basic food products and their accessibility to the population" [2]. Supports the position of L.V. Pushkareva Associate Professor of the National Open Institute of Russia (NOIR) Ph.D. Gorokhova T.B.: "To create a stable food base in Russia, which is under constant political pressure of various kinds of sanctions, it is advisable to recognize the formation of the food complex in the country as an important strategic direction" [1].

Negative trends emerging in the agricultural sector of the economy of the North-West Economic Region were identified back in the early 2000s by specialists of St. Petersburg State University in the monograph "North-West: The Thorny Path to the Market" and their parameters were described: "Of particular concern deterioration in the diet of the bulk of the population, which does not contribute to improving the health of the population, negatively affects demographic indicators and labor productivity. For 1991-2000 the consumption of meat and meat products per capita in St. Petersburg decreased by $48 \%$, in the region - by $26 \%$, milk and dairy products - by $55 \%$ and $53 \%$, eggs - by $20-21 \%$, respectively "[3]. Changes in consumer demand are explained by the lack of supply of these 
products of own production in the regional market. The reason is the massive malnutrition and mortality of cattle and pigs by more than $50 \%$, and poultry by $35 \%$. Due to the lack of imported feed grain from Belarus and Ukraine, interruptions in the supply of feed from the southern grain regions of Russia, large agricultural enterprises of the region were forced to reduce their livestock numbers. At the same time, personal subsidiary plots of the population raised cattle and small cattle, although this measure of food supply could not compensate for the losses suffered by agriculture. The upward trend in the number of personal subsidiary plots was caused, first of all, by unemployment in the countryside and the decline in incomes of the urban population, which was forced to turn to rural labor, while solving the problem of recreation. Farming also did not live up to the expectations of the reformers. In the absence of well-thought-out organizational measures, not supported by financial and legal state support, already at the initial stages the idea of farming ended in failure. By the beginning of the 21st century, the share of agricultural farm products amounted to only $1.6 \%$ of agricultural output. Successful farmers are those who operate in the suburban area. A significant number of farmers are only listed as such.

This situation prevailing in domestic agriculture contributed to the entry of foreign investors into the Russian food market. The most favorable economic and legal conditions were created for them. The concentration of foreign capital is noted in the Russian food industry. This means that foreign investors do not invest in labor-intensive agricultural sectors. Their investments were directed mainly to enterprises processing agricultural raw materials, focused on the rapid sale of food products to the local population. According to experts, the share of foreign capital in Russian agriculture is $60 \%$, and this figure continues to grow. Moreover, in relations with foreign investors in the field of the food market, a tendency has been identified that is characterized by circumstances: a strong agricultural enterprise that appeared on the market or a new food brand that is in demand among customers is immediately acquired by foreign corporations.

It is the difficulties of the Russian economy and the possibility of quick enrichment due to domestic troubles, and the unequal participation in business that guide foreign corporations to participate in the Russian food market. For foreign corporations, the following circumstances are the most attractive criteria for entering the Russian food market:

- The Russian food market, due to its large population, is the largest food supply in the world;

- the food industry of the Russian Federation does not have its own production and does not fully provide its population with food;

- statistics show that the population of the Russian Federation does not receive the necessary amount of food per capita due to world biological standards;

- the territory of the Russian Federation has a favorable raw material feed base for cattle breeding, pig and other animal breeding, conditions for creating a grain farm, vegetable growing;

- The tax system of the Russian Federation provides attractiveness for foreign corporations to participate in the food market with low income taxes;

- lack of work experience for domestic agricultural entrepreneurs in a competitive environment with skilled foreign managers and lobbyists.

Recent transactions by transnational corporations in the Russian food and beverage market include the following: the acquisition of PepsicCo-Wimm-Bill-Dann "for 5.4 MDDR. dollars; during the creation of a joint venture - Danone - Yumilak - Danone "paid 120 million to shareholders. Euro for a controlling stake of $57.5 \%$ in the new enterprise; $\$$ 1.4 billion was paid for the acquisition of PepsicCo- Lebedyansky with a $75.53 \%$ stake; Acquisition of Coca -Cola Nidan Plant Costs \$ 276 Million; acquisition of Univlever CJSC Baltimore Holding - in the amount of $40 \mathrm{mln}$. dollars [4, S.582-599] 
Based on the foregoing, the prospects for the development of the domestic agricultural sector of the Russian economy remain vague. Noticeable shifts in agriculture should be expected only with appropriate state agricultural and food policies. If further participation of Russia in the WTO is not stipulated by special conditions, the agricultural sector of the economy may be further undermined. It is worth noting that in such segments of the food market as the meat processing market and the bakery products market, domestic enterprises still maintain leadership [4]

For many years of many years of research on the distribution of productive forces in the Russian Federation, modeling in the agricultural sector of the economy was hampered by the complexity of taking into account numerous external factors in inter-regional relations due to climatic and technological differences. But attempts to simulate domestic agriculture are repeatedly repeated in leading scientific organizations, which include the academic institutes of the Russian Academy of Sciences and All-Russia Research and Development Institute of Agricultural Economics. As a rule, 78 regions of the country are considered in scientific developments, and, in particular, a forecast for the development of the food base in the cities of Moscow and St. Petersburg is separately developed. Current forecasts are focused on the development of strategies taking into account indicators characterizing the state of agricultural production. These include: land resources; the level of equipment of the agricultural sector of the economy with basic means of production; working capital, in terms of the use of planting seed material of domestic and imported origin; protection against diseases and pests; labor is lively and mechanized; livestock structure of the herd; feed base, including an important component - feed grain. At the same time, special attention is paid to the development of grain farming. [5]

After the separation of the grain zone of Ukraine and Belarus from Russia, the trend of a geographical shift in grain farming was outlined in the southern part of Western Siberia and the Non-Black Earth Region. The location of livestock and poultry farms, which are the main consumers of feed grain, is oriented to the Moscow, Leningrad, Tula regions and Tatarstan. At the same time, neighboring regions (Smolensk region), importing dairy products from Belarus, become the main suppliers of dairy products. In the Belgorod region, preconditions have been outlined for increasing the supply of meat, and in the Voronezh region - grain. Cattle and poultry meat production will also increase in the Pskov, Vologda, Kirov regions, and in the Perm Territory and the Republic of Bashkortostan there will also be growth, but slightly weaker. The successes of these regions are determined by:

- firstly, the difference in transport logistics and the presence of the largest sales markets in Moscow and St. Petersburg;

- secondly, a shift in the north and north-east direction of natural agricultural zones.

In traditional grain regions in the European part of the Russian Federation to the Ural Range, the expected changes in grain farming are insignificant. A slight increase in grain production is expected in the Pskov and Yaroslavl regions, which mainly tends to be located in the south of these regions. The increase in grain production will occur in Orenbug. Due to the improvement of the competitive position of the Non-Black Earth Region, a decrease in the share in grain production of the Kuban and Voronezh region is expected.

The transformation period also affected the agricultural complex of the North-West Economic Region. Since the beginning of the 1990s, the region's agriculture has suffered the most significant losses during the reform period. However, the economy of St. Petersburg remained traditionally oriented towards covering the food needs of its residents. This feature of the economy of the post-siege city led to an increase in the share of the food industry (from 1991-2000 from 13 to 35\%). For the Leningrad region over the same period, an increase in the share of the food industry was from 8 to $17 \%$. Despite a tangible increase in the share of the food industry in total production, sales volumes of most socially 
significant goods do not exceed the pre-reform level, and a noticeable decline was noted for some food products. These include meat products, pasta, whose production fell by $1 / 3$.

As for St. Petersburg, the city does not participate in supporting agriculture, which provides for a significant part of its food needs. In St. Petersburg, in spite of the absence of close economic ties with domestic regional producers of agricultural products, the city food market is provided by external suppliers with the necessary food products. The bread market is developing especially rapidly. For only one 2017. the number of private bakeries increased by $40 \%$ compared to the previous 2016 . It should be noted that in St. Petersburg the number of new bakeries outnumbers similar Moscow private small enterprises. Petersburg bakeries are popular with the local and visiting population and become an integral part of the city.

Especially great popularity and a corresponding increase in the number of establishments is distinguished by such a segment of the bread market as "fresh baked goods at home". According to the Russian Guild of Bakers and Confectioners (RosPiK), which unites manufacturers of bakery products of different levels, currently 1,148 bakeries and bakery are registered. Moreover, these bakeries do not include restaurant units and supermarket departments working in the city. The growth in the number of bakery shops is due to the rapid development of the bread market chains. For example, in just 5 years within the city limits, the number of "Volchek's Bakery" has grown to 90. The chain of shops "Cekh 85", which was opened by co-owners of jewelry stores, has 50 outlets. Along with the growth of private bakery enterprises in St. Petersburg, the production of bakery products is increasing. So, since 2012. the volume of bakery products increased from $260 \mathrm{t}$ to 280t. According to RosPiK, such rates of growth in bread production are not typical for Russia as a whole. The total volume of bread production in the country tends to decrease.

The participants of the St. Petersburg bread market explain the bread boom in the city for the following reasons:

- firstly, St. Petersburg has always followed European traditions. Being a major tourist center in the city spreads the European lifestyle "in the morning a cup of coffee with fresh pastries";

- secondly, the urban population of the older generation remained in the habit of buying fresh bread in bakeries;

- thirdly, the St. Petersburg weather, which is not very predictable, is suitable for hikes in mini-cafes and snacks in anticipation of the end of the rain.

Of course, there are economic reasons for the development of the bread market in the city. Many businessmen who are engaged in baking, believe that the crisis that befell large catering enterprises has created a need for buyers to have an inexpensive meal for 150-300 rubles somewhere. Private bakers and pastry chefs responded to the demand of the population, which led to the opening of coffee shops, where the average cost of a visitor to a restaurant is $150-175$ rubles, which is almost $30 \%$ lower than the average consumer spending on a cafeteria.

According to the leaders of RosPiK, in St. Petersburg the market for "fresh baked goods" is far from satiety, because the specific indicator of production volumes per 10 thousand inhabitants reached the level of 0.76 , and in developed European countries this indicator is more than 3-4.

On the pages of the newspaper "Delovoy Peterburg", fears have repeatedly been expressed that the rapid development of private bakeries could undermine the industrial production of bread. In different regions of the country, industrial production of bread for 2018 fell by $1-2 \%$. RosPiK regards this situation as the inability of large bakeries in many regions of the country to respond to the tastes and needs of customers, while small private bakeries cope with this problem. The weakening consumer demand for industrial bread is forcing domestic factory producers to open their own mini-bakeries and pastry shops. There 
are successful manufacturers in this direction. For example, the leader of the St. Petersburg bakery market is Fazer, which is developing the Baker's Market bakery network. The second in terms of production of bakery products is the producer "Karavay". Under his management, a network of cafes of the same name is located - confectionery. The large bread producer "Darnitsa" works closely with the network "Lyudi lyubyat hleb". The centers of the grain trade, often formed near metro stations, along tourist routes, in the central areas of the city.

\section{Conclusions}

Thus, the current situation in the bread market indicates the initial stage of development of bread clusters, where specific traditions and regulations for the functioning of producers were formed to a certain extent. With regard to other participants in the food market and the development of a full-fledged food cluster, it is too early to speak. However, successes in the development of the bread market in St. Petersburg show that positive results are also achievable in different segments of the food market in other regions of the country.

\section{References}

1. K.V. Averkieva, A.I. Dan'shin, D.Y. Zemlyanskii, and S.V. Lamanov, Strategic challenges of the development of agriculture in Russia. Regional Research of Russia 7(4), 322-332 (2017).

2. L. Pushkareva, Economic Security Issues (2019). doi: 10.2139/ssrn.3505157.

3. F.F. Rybakov, A.I. Chistobaev, K.V. Shkonda, North-West of Russia: the thorny path to the market (2002).

4. N.M. Svetlov, S.O. Siptits, I.A. Romanenko, N.E. Evdokimova, The effect of climate change on the location of branches of agriculture in Russia. Studies on Russian economic development 30(4), 406-418 (2019).

5. W. Strielkowski, E. Volkova, L. Pushkareva, D. Streimikiene, Innovative Policies for Energy Efficiency and the Use of Renewables in Households. Energies 12(7), 1392 (2019). 